\title{
20. LITHOLOGIC AND GEOCHEMICAL CHANGES ACROSS UNCONFORMITIES AT SITE 612, DEEP SEA DRILLING PROJECT LEG 95, NEW JERSEY TRANSECT ${ }^{1}$
}

\author{
Michel Cousin, Université Pierre et Marie Curie \\ and \\ Jean Thein, Universität des Saarlandes ${ }^{2}$
}

\begin{abstract}
Seven unconformities were recognized in the stratigraphic section at Site 612: (1) a transition between clayey Campanian chalk and less clayey Maestrichtian chalk; (2) a poorly recovered Cretaceous/Tertiary boundary interval in which a 9-m gap in the section appears to represent 12 m.y. of geologic time; (3) an unconformable contact between the lower Eocene and middle Eocene associated with silica diagenesis; (4) a microtektite horizon between the middle and upper Eocene intervals; (5) a contact between pelagic Paleogene sediments and terrigenous Neogene deposits; (6) a Tortonian/ Messinian contact marked by centimeter-sized grains and various lithoclasts derived from older units; and (7) a contact between Pliocene alternating clay and glauconitic sand and homogeneous gray Pleistocene clay. Sea level fluctuations appear to have been an important factor in the development of many of these unconformities.
\end{abstract}

\section{INTRODUCTION}

The purpose of Leg 95 was to study the continental slope and rise of the New Jersey Margin. Two sites were drilled, Site 612 in the midslope region and Site 613 on the upper rise. These sites complete part of a transect begun on Leg 93 with Sites 604 and 605 . Site 612 penetrated Cenozoic and Upper Cretaceous strata, whereas only a partial Cenozoic section was recovered at Site 613 . Particular attention was given to the identification of unconformities and erosional features.

The purpose of this study is the lithologic and geochemical description of the sediments above and below the unconformity surfaces. These data are used to interpret the origin of the unconformities in terms of regional paleoceanographic events.

The original intent of this study was to analyze all the sites in the New Jersey Transect. Because of dense core sampling, however, this was only possible for Site 612 . General results from the other sites (Sites 604, 605, and 613 ) are discussed in the conclusions.

\section{Site 612 Unconformities}

\section{Regional Geological Setting}

Leg 95 drilling was undertaken as part of a broad study of the U.S. Atlantic continental margin. United States Geological Survey (U.S.G.S.) seismic Line 25, which crosses the margin in a WNW-ESE direction beginning $25 \mathrm{~km}$ offshore New Jersey and continuing to the continental rise, was used as the principal stratigraphic reference section (Fig. 1). This line is part of a dense network

\footnotetext{
${ }^{1}$ Poag, C. W., Watts, A. B., et al., Init. Repts. DSDP, 95:Washington (U.S. Govt. Printing Office).

Addresses: (Cousin) Laboratoire de Géodynamique Sous-Marine, Université Pierre et Marie Curie VI, C.E.R.O.V., B.P. 48, 06230 Villefranche-sur-Mer, France; (Thein) Fachrichtung 15.5, Angewandte Geochemie, Universität des Saarlandes, D6600 Saarbrücken, Federal Republic of Germany.
}

of profiles collected by the U.S.G.S. and the Bundesanstalt für Geowissenschaften und Rohstoffe (BGR), and by Woods Hole Oceanographic Institution and LamontDoherty Geological Observatory (Poag and Mountain, this volume). Numerous exploratory boreholes, including the COST B-3 well, provide stratigraphic control (see Poag, 1985a).

Leg 95 was intended to complement a previous series of studies of the New Jersey Margin that includes: (1) a geological cross section along U.S.G.S. Line 25 (Fig. 2; Schlee and Grow, 1980; Grow, 1980; Poag, 1985a), (2) the stratigraphy of the thick Baltimore Canyon Trough sequence and its relationship to sea level changes (Poag, 1980, 1985a; Vail et al., 1977; Vail and Hardenbol, 1979; Poag and Schlee, 1984), and (3) structural and thermal evolution of the margin (Watts and Steckler, 1979). Results from Leg 95 are valuable in refining interpretations from these studies, particularly regarding the continental slope region (see Miller et al., 1985; Poag and Schlee, 1984; Poag, 1985a, 1985b; Watts and Thorne, 1984).

\section{Stratigraphic Sequence}

Site 612 is located in the middle part of the continental slope $\left(38^{\circ} 49.21^{\prime} \mathrm{N}, 72^{\circ} 46.43^{\prime} \mathrm{W}\right)$, in $1404.3 \mathrm{~m}$ of water. A total of $674 \mathrm{~m}$ of sediments were drilled, with five lithologic units distinguished, dated from Campanian to Quaternary. Detailed sedimentologic and biostratigraphic reports on Site 612 appear in the Site 612 chapter (this volume; see Poag, 1985b).

The major lithologic sequences, beginning at the base of Hole 612, are as follows (Fig. 3):

1. $27.8 \mathrm{~m}$ of alternating clays and black chalks (Unit $\mathrm{V})$; rich in organic matter and pyrite, with frequent bioturbation and Inoceramus fragments. Nannofossils and planktonic and benthic foraminifers indicate a Campanian age. The microfossil assemblages (particularly the low ratio of planktonic to benthic foraminifers, $3: 1$ ), in conjunction with lithology, indicate an outer shelf setting. 

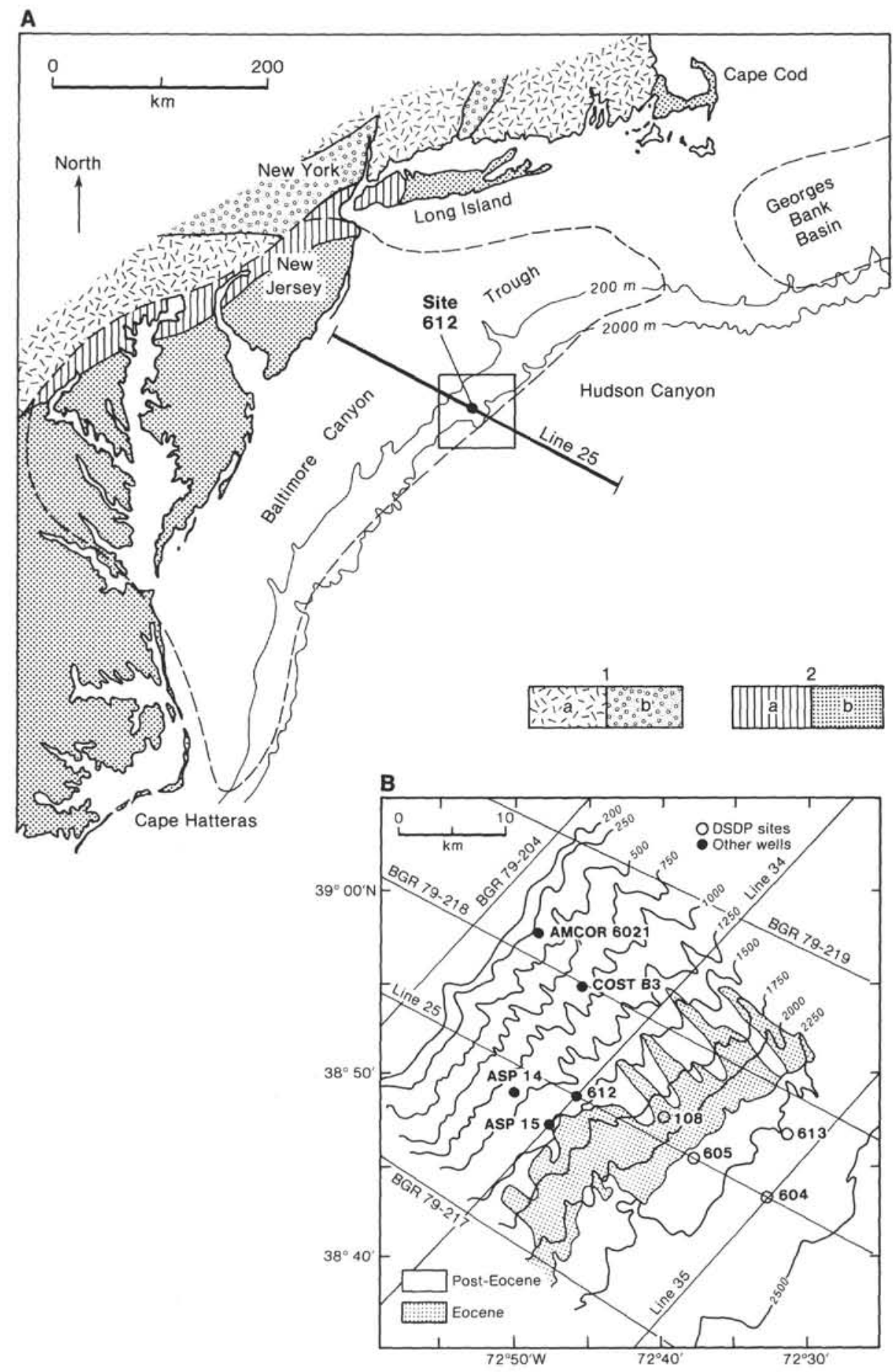

Figure 1. A. Location of Site 612 and U.S.G.S. multichannel seismic Line 25 off New Jersey (modified from Poag, 1985a). Legend: $1 \mathrm{a}=$ Appalachian fold belt, $1 \mathrm{~b}=$ Triassic-Liassic rift basins; (2) Atlantic Coastal Plain: Cretaceous (2a) and Tertiary or Quaternary (2b) sediments. B. Location of Site 612 and other wells on the New Jersey continental slope and upper rise (modified from Robb et al., 1981).

2. $84.6 \mathrm{~m}$ of gray to black marly chalk, highly bioturbated, with some lithified limestone layers (Unit IV). Pyrite nodules frequently occur and glauconitic horizons appear, especially at the base and top of the unit. As in the underlying section, Inoceramus shell fragments occur, as does a rich assemblage of benthic and planktonic microfossils (outer shelf setting). A greater pelagic in- fluence than during the Campanian is indicated by the higher ratio between planktonic and benthic foraminifers $(9: 1)$ and the appearance of rare radiolarians. This microfossil association is assigned to the Maestrichtian.

3. $231 \mathrm{~m}$ of nannofossil-rich siliceous chalk alternating with light green to olive green porcellanite. Some layers are thinly laminated. Other intervals are homoge- 
A

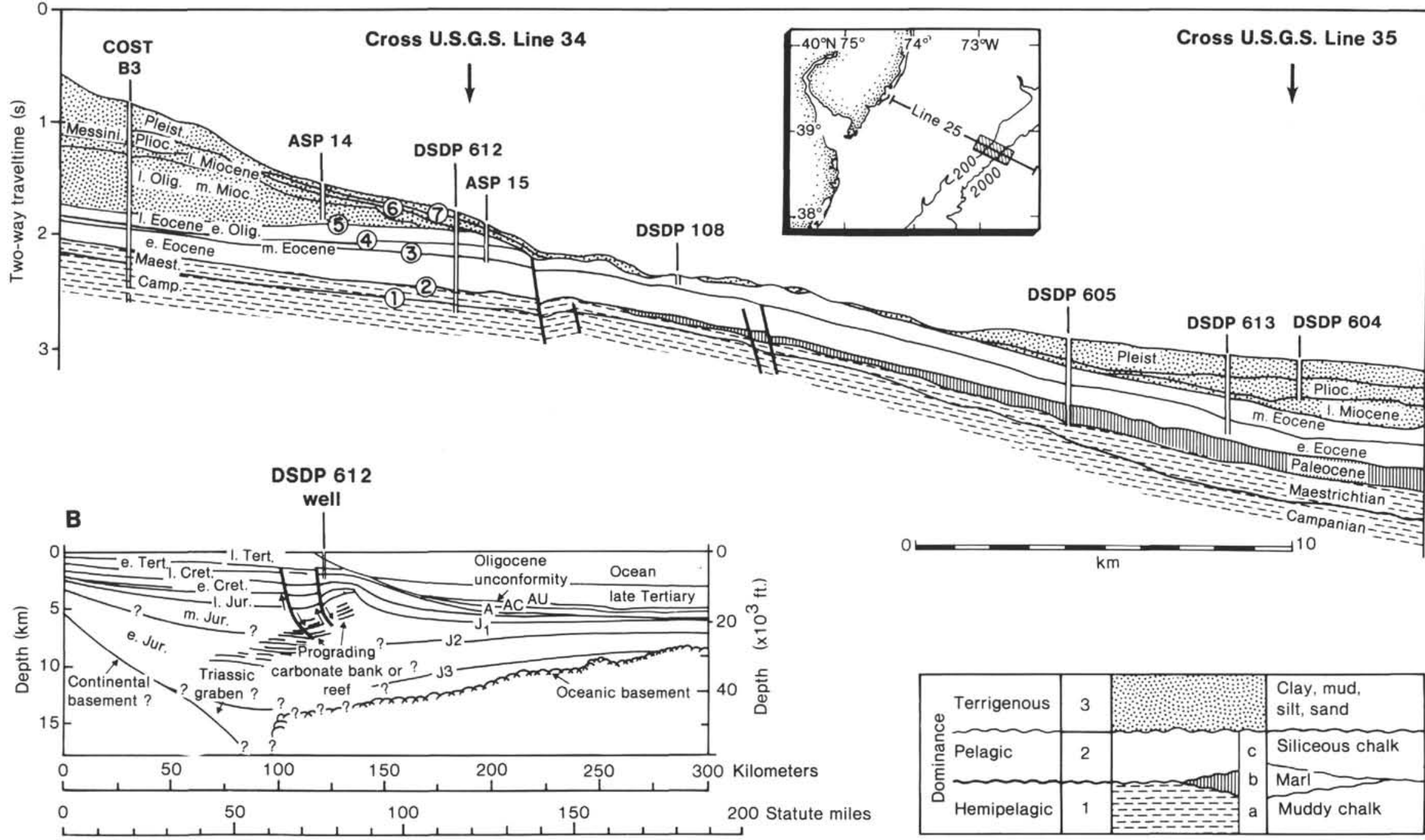

Figure 2. Cross sections along U.S.G.S. Line 25. A. Section along the continental slope (modified from Poag, 1985b); 1-7 = unconformities described in this chapter; ASP = Atlantic Slope Project (Poag, 1985a). Only Site 612 is on Line 25, the other sites are projected to it. B. Geologic section across Baltimore Canyon Trough (from Grow, 1980, simplified). 


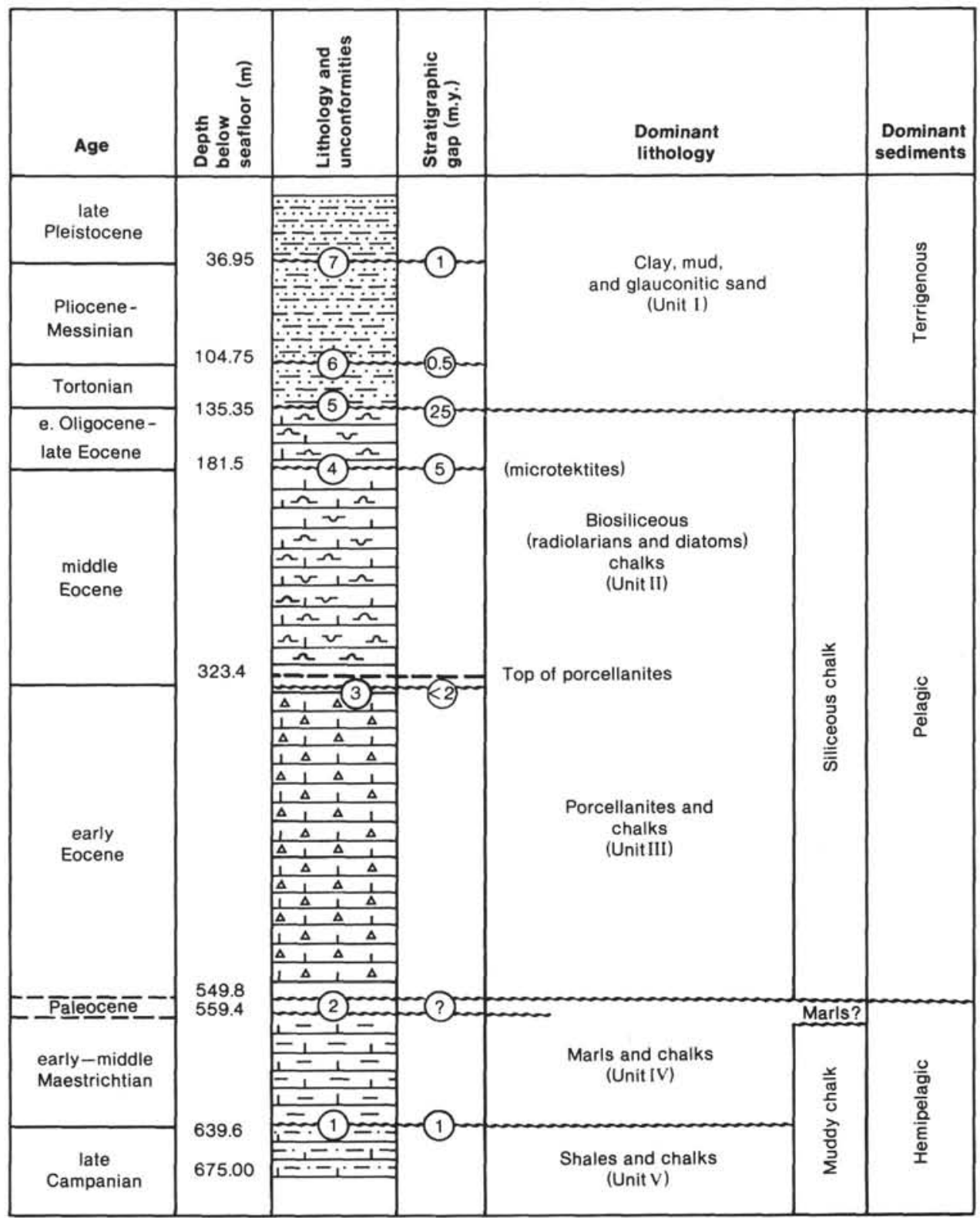

Figure 3. Sedimentary sequences and unconformities at Site 612.

neous and strongly bioturbated (with some burrows up to $10 \mathrm{~cm}$ in length). The lithification observed (porcellanite) is related to silica cement derived from the dissolution of radiolarians and diatoms (Wilkens at al., this volume). Nannofossils, planktonic foraminifers, and radiolarians indicate an early to early middle Eocene age for this unit.

4. $187.4 \mathrm{~m}$ of slightly lithified biosiliceous chalk (Unit II), consisting of calcareous nannofossils, planktonic foraminifers, radiolarians, diatoms, and sponge spicules in a matrix of clay and amorphous opal (opal A). The sediment is highly bioturbated; it contains a microfossil assemblage indicating a middle Eocene to early Oligocene age. This section is interpreted to have been deposited in well-oxygenated bathyal depths.

5. $135 \mathrm{~m}$ of alternating gray clay and glauconitic sand, Neogene in age (Unit I). The sudden increase of terrige- nous components correlates with a marked decrease in the carbonate content $(<10 \%$, compared with $30-60 \%$ in the Cretaceous and Paleogene sections). The three subunits in the Neogene interval are as follows:

a. $28.4 \mathrm{~m}$ of grey and greenish gray clay containing rare barite concretions and gypsum cement; diatoms are abundant; nannofossils, planktonic foraminifers, and radiolarians indicate a late Miocene age (Subunit IC).

b. $69.65 \mathrm{~m}$ of alternating bioturbated clays and glauconitic sand with occasional graded bedding; a debris flow occurs at the base of this Pliocene unit (Subunit IB).

c. $36.85 \mathrm{~m}$ of grey to black homogeneous clay with pyrite framboids and frequent burrows with quartz sand and glauconite; this section (Subunit IA) is assigned to the late Pleistocene. 


\section{Unconformities}

Seven important unconformities occur in the stratigraphic sequence of Site 612 between the major lithologic units or subunits, and most are represented by an erosional surface and a biostratigraphic gap:

1. The contact between the Campanian chalk (strongly deeply bioturbated) and the Maestrichtian chalk.

2. The difference between the Cretaceous section and the Paleogene section (although the actual contact was unfortunately not recovered).

3. The lower Eocene/middle Eocene contact and associated diagenetic front.

4. A biostratigraphic gap between the middle and upper Eocene, above which is a microtektite horizon, marked by a large geochemical anomaly.

5. The contact between the calcareous Paleogene units and the terrigenous Neogene formations, marked by a 25 m.y. biostratigraphic gap.

6. The contact between the Tortonian clays and the bottom of the debris flow at the base of the Messinian section.

7. The contact between the clay and glauconite sand of the upper Pliocene and the terrigenous mud of the upper Pleistocene.

\section{MAJOR FEATURES OF THE UNCONFORMITIES}

The macroscopic descriptions and shipboard biostratigraphy are briefly discussed for each unconformity, and new data on the microscopic features (observed in thin sections and smear slides) and geochemical bulk sediment analyses are presented. The geochemical patterns are given in Figure 4, and the summarized data appear in Figures 5 to 9.

\section{Contact between Campanian and Maestrichtian Chalks (Fig. 5)}

The Upper Cretaceous is represented at Site 612 by a grayish or black chalk facies, more clayey in the Campanian, more calcareous in the Maestrichtian. The contact between the two sub-facies occurs in Sample 612-69-3, 8 $\mathrm{cm}$ (639.6 m sub-bottom). The Maestrichtian chalk is glauconitic at the base and appears to penetrate deeply into the underlying Campanian in burrows. This macroscopic observation helps explain the presence of the Maestrichtian foraminifer assemblage a few centimeters below the main lithologic contact. Poag and Low (this volume) estimate that a hiatus of approximately $1 \mathrm{~m} . \mathrm{y}$. is represented by this unconformity.

The contact is poorly defined in microscopic examination. A gradual transition is observed between the finegrained clayey Campanian chalk and the coarsergrained, glauconitic, and microfossil-rich Maestrichtian chalk. Bioturbation may mix these two lithologies over a very fine scale and may be at least in part synchronous with the first deposition of Maestrichtian foraminiferal packstones.

The main geochemical variations between the top of the Campanian and the base of the Maestrichtian are (1) an increase in calcite and manganese above the unconformity, (2) a systematic decrease of terrigenous clay- related elements $\left(\mathrm{Al}_{2} \mathrm{O}_{3}, \mathrm{~K}, \mathrm{Cu}, \mathrm{V}, \mathrm{Cr}, \mathrm{TiO}_{2}\right)$, and (3) a trend back toward Campanian values $30-40 \mathrm{~cm}$ above the unconformity.

We conclude that the observed lithologic discontinuity coincides with a biostratigraphic gap representing the Campanian/Maestrichtian contact. The temporary decrease in clay-related elements immediately above the unconformity appears to be related to a diminished terrigenous fraction, which coincides with the end of the Campanian transgressive sequence. Bioturbation is important at the Campanian/Maestrichtian contact.

\section{The Cretaceous/Tertiary Contact}

The transition between the Cretaceous and Paleogene lies within the interval drilled in Core 612-60, between 559.4 and $549.8 \mathrm{~m}$ sub-bottom. Unfortunately, only $80 \mathrm{~cm}$ of lower Eocene sediment was recovered from this interval. Thus, a gap of only $9 \mathrm{~m}$ in the section represents $12 \mathrm{~m}$.y. of geologic time, from the early middle Maestrichtian to the early Eocene.

The features observed regarding this presumed unconformity are

1. Persistent high carbonate content (nannofossil foraminifer chalk) above and below the unconformity.

2. Persistent strong bioturbation of sediments, with burrows reaching down to $10 \mathrm{~cm}$, reflecting well-oxygenated bottom conditions.

3. Upward decrease in terrigenous influx (quartz and clay).

4. Upward increase in biosilica (clayey porcellanite produced by a large number of dissolved radiolarian tests).

The presence of an unconformity is speculative as recovery was low in this interval. However, the observed peaks in the downhole gamma-ray measurements between 556 and $552 \mathrm{~m}$ sub-bottom may indicate the presence of a Paleocene clay interval (as observed at Site 605).

\section{The Early Eocene-Middle Eocene Unconformity and Associated Diagenetic Front}

This contact is an unconformity observed between the lower and middle Eocene (Poag and Low, this volume, figs. 11, 12) which coincides with a biostratigraphic gap of $<2 \mathrm{~m}$.y. and a change in the terrigenous content.

This contact lies $8 \mathrm{~m}$ below a diagenetic siliceous front placed by Thein and von Rad (this volume, according to opal A/opal CT ratios) in Section 612-36-4 (323.4 m sub-bottom) in the lowermost part of the middle Eocene. However, partly lithified calcareous horizons occur in the overlying siliceous chalk up through Core 612-28 (245 m sub-bottom; see Wilkins et al., this volume).

Therefore, at Site 612 the diagenetic front cannot be distinguished on seismic profiles from the unconformity at the lower Eocene/middle Eocene contact. In other parts of the North American basin, the top of the porcellanites appears to correlate with a very strong seismic reflection (Tucholke, 1979).

\section{Middle/Upper Eocene Contact and Associated Microtektite Layer (Figs. 4C, 6)}

The sequence of light gray chalk and biosiliceous calcareous ooze in Section 612-21-5 is interrupted by a $20-\mathrm{cm}$ - 


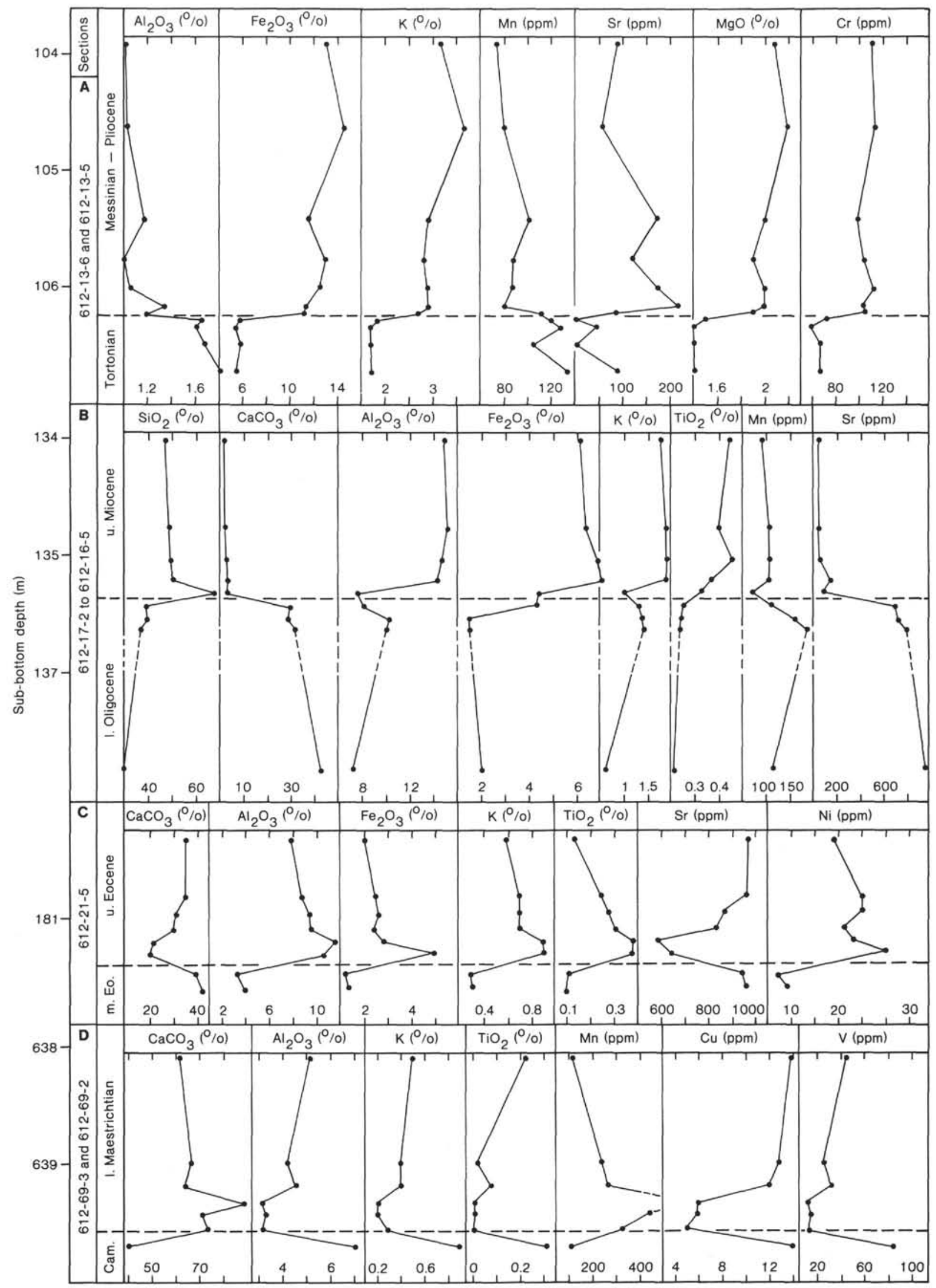

Figure 4. Element variation patterns across the unconformities at the Campanian/Maestrichtian (D), middle Eocene/upper Eocene (C), lower Oligocene/upper Miocene (B), and Tortonian/Messinian (A) contacts at Site 612. 


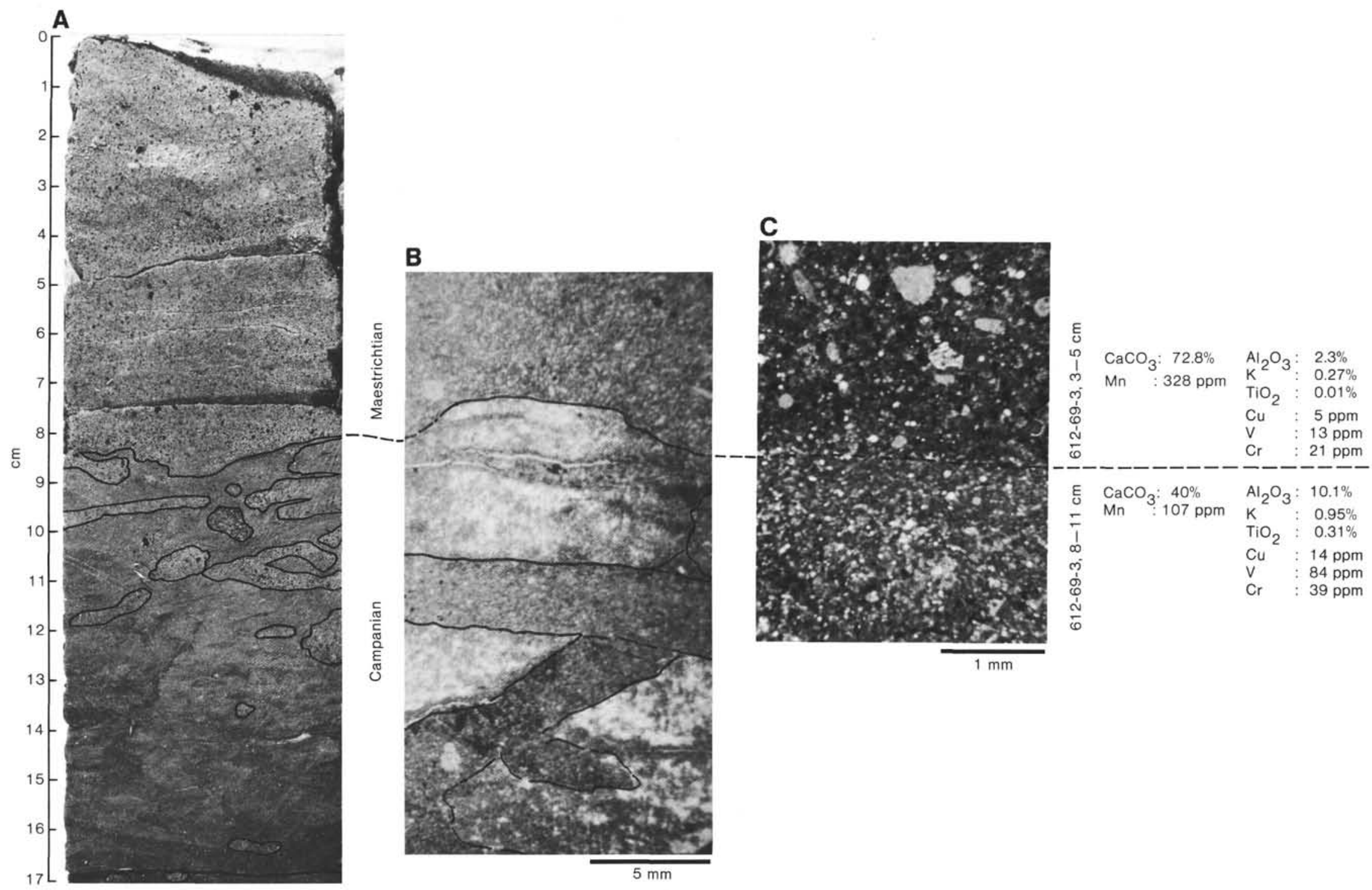

Figure 5. Contact between Campanian and Maestrichtian chalks at Site 612; the coarse-grained Maestrichtian chalk appears to penetrate deeply into the underlying Campanian in burrows (A, photo of Core 612-69-3; B, thin section; C, detail of the main contact; also correlative geochemical variation [upward decrease of terrigenous clay and related elements]). 

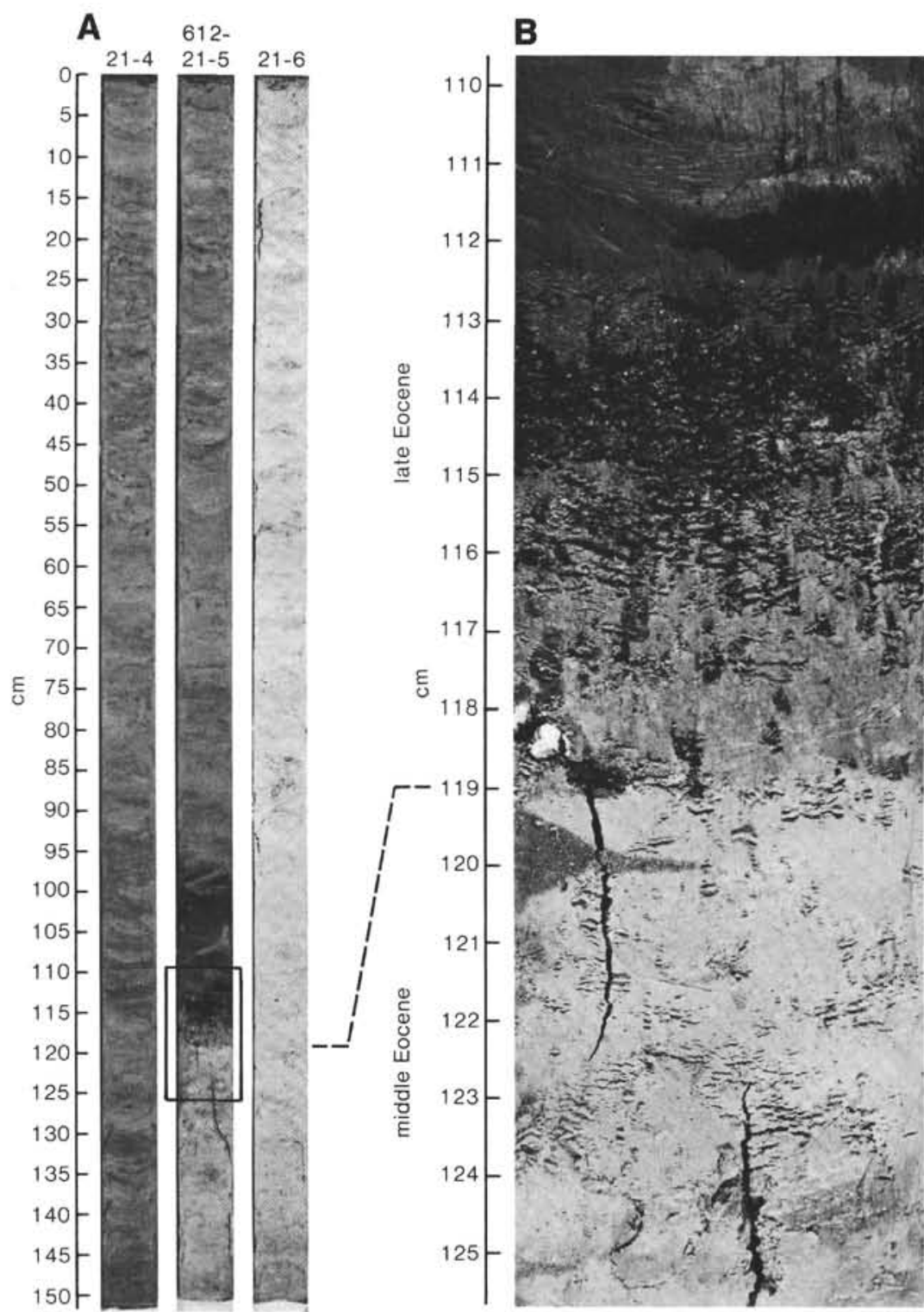

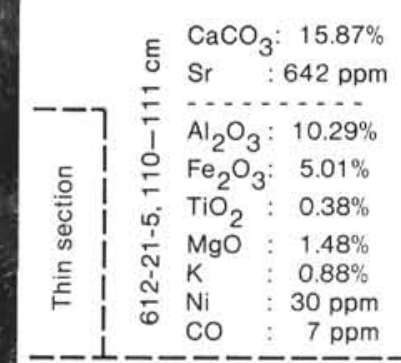

C

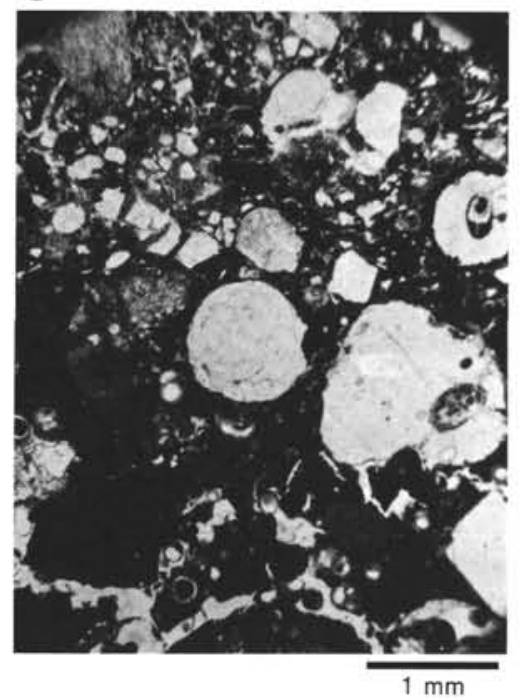

Base of the glassy glauconitic sand

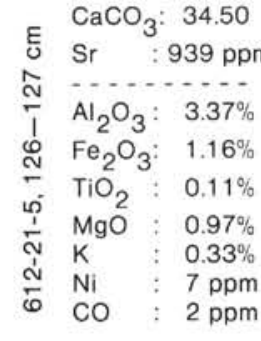

Figure 6. Microtektite layer at the middle/upper Eocene contact at Site 612 (A and B, core photos; C and D, fragments of glass, tear-shaped microtektite, and spherical bubbles in a matrix of foraminifer-bearing clayey nannofossil chalk; geochemical anomalies are related to the presence of microtektites). 
thick darker interval (base in Sample 612-21-5, $119 \mathrm{~cm}$, $181.5 \mathrm{~m}$ sub-bottom). A biostratigraphic gap of approximately $5 \mathrm{~m} . \mathrm{y}$. is indicated at this level by foraminifers, nannofossils, and radiolarians (Poag and Low, this volume). In particular, dense nannofossil and foraminiferal sampling places the hiatus between Samples 612-21-5, $111 \mathrm{~cm}$ and $612-21-5,121 \mathrm{~cm}$.

The sandy layer overlying the eroded unconformity surface contains microtektites (observed in thin sections from Sample 612-21-5, 111-144 cm; see also Thein, this volume). These objects are ellipsoidal, spherical, or teardrop shaped, approximately $1 \mathrm{~mm}$ in diameter. They are associated with angular to subangular glassy fragments with spherical vesicles and a fluid texture. A preliminary analysis by neutron activation (U. Rast and G. Graup, pers. comm., 1985) indicates that the glass is of impact rather than volcanic origin, consistent with the identification of microtektites.

The microtektites occur with foraminifers, radiolarians, partly shocked quartz, feldspar, glauconite grains, and clay intraclasts. Several other such coarse-grained beds occur in the chalk just above the unconformity.

The large geochemical anomalies observed across the unconformity appear to be related to the presence of the microtektites. A large increase in $\mathrm{Al}_{2} \mathrm{O}_{3}, \mathrm{Fe}_{2} \mathrm{O}_{3}, \mathrm{~K}$, $\mathrm{TiO}_{2}, \mathrm{Ni}, \mathrm{MgO}$, and $\mathrm{Co}$ (Figs. $4 \mathrm{C}, 6$ ) is measured at the level of the microtektite horizon, while $30-40 \mathrm{~cm}$ above this horizon values are similar to those below the unconformity. Therefore, the increase of $\mathrm{Fe}$ and $\mathrm{Ni}$ content may not be related to the increase of terrigenous minerals; these appear to have been generated by impact of an extraterrestrial body.

No relationship is seen between the original microtektite deposition (apparently the impact product of an extraterrestrial body) and the erosional surface that marks the unconformity. The most reasonable interpretation is that the impact that generated the microtektites and associated materials probably occurred before the submarine erosion episode that redeposited the microtektite debris.

\section{Contact between the Paleogene Pelagic Sediments and Neogene Terrigenous Sediments (Figs. 4B, 7).}

The unconformity having the longest hiatus at Site 612 occurs in Sample 612-16-6, $116 \mathrm{~cm}$ (135.35 m subbottom; Fig. 7). In this core a very clear contact separates the Paleogene chalk from a $10-\mathrm{cm}$-thick horizon of coarse-grained glauconitic sand, which underlies the Miocene micaceous clay above. A sample from the chalk taken $2 \mathrm{~cm}$ below the contact (Sample 612-16-6, 117$119 \mathrm{~cm}$ ) contains foraminifers indicative of Zone P18 (early Oligocene); this age is confirmed by nannofossils and radiolarians. Above the contact, the micaceous clays contain late Miocene foraminifers, nannofossils, and radiolarians, indicating a biostratigraphic gap of approximately 25 m.y. (Site 612 chapter, this volume; Poag and Low, this volume).

Thin sections reveal that the uppermost part of the Paleogene series is enriched in biogenic material: 25-
$30 \%$ nannofossils, $25-30 \%$ diatoms, radiolarians, and foraminifers. The biogenic fraction occurs in a matrix of clay and fine-grained calcite. The microfauna is often pyritized and glauconitized. This lithology is scoured at the unconformity by a coarser-grained sediment with average grain size $1.5 \mathrm{~mm}$ (range $0.1-3 \mathrm{~mm}$ ) and consisting of quartz, plagioclase, and a few glauconite grains. The transition zone is enriched in opaque minerals (at the top of the calcareous unit). At the base of the coarsegrained unit there is a discontinuous horizon, reddish in color, which represents a hardground. The glauconite at this level is rust red or full of opaque minerals. This could be the result of etching by fluids passing through the porous, coarse-grained interval.

Higher in the unit, the grain size decreases slightly (0.8-1 mm average); quartz is most abundant, feldspars are often corroded and filled with glauconite, and detrital mica, pyroxenes, epidote, pyrite, and gypsum crystals are present, all within a clay matrix.

The geochemical analysis (Fig. 7) of samples across the unconformity shows an increase in $\mathrm{SiO}_{2}, \mathrm{Al}_{2} \mathrm{O}_{3}, \mathrm{~K}$, and $\mathrm{TiO}_{2}$, and a decrease in $\mathrm{CaCO}_{3}$ and $\mathrm{Sr}$; this trend indicates that, in general, terrigenous detrital components are enriched and biogenic components depleted above the unconformity. However, some deviations from this pattern are observed (Fig. 4c). For instance, a positive $\mathrm{SiO}_{2}$ peak and negative $\mathrm{Al}_{2} \mathrm{O}_{3}, \mathrm{~K}$, and $\mathrm{Mn}$ peaks appear just above the contact. This corresponds to the glauconitic sand horizon, at the base of the Neogene series.

In conclusion, this unconformity: (1) represents a biostratigraphic gap of 25 m.y.; (2) is distinguished by a sandy horizon marked by a well-defined geochemical pattern related to the lithologic change, (3) features observed at the level of the unconformity such as etching, formation of concretions and a possible hard ground suggest a long period of marine erosion and/or nondeposition; (4) a distinct change in sedimentation regime across the unconformity is evident, especially demonstrated by the pattern of geochemical elements. The values measured in overlying samples are consistently different from those of the underlying sediments; and (5) this unconformity marks a significant division in the section at Site 612, with biogenic carbonate (and silica) dominating the lower sequence and detrital terrigenous material predominant in the upper.

\section{The Late Miocene Unconformity (Figs. 4A, 8)}

A clean contact, observed in Sample 612-13-6, $95 \mathrm{~cm}$ $(104.75 \mathrm{~cm})$ separates Miocene clays from an overlying debris-flow unit consisting of centimeter-sized fragments (including a $3-\mathrm{cm}$ bone fragment, Fig. 8) and various lithoclasts derived from older units. These components are surrounded by a matrix of clay and glauconitic sand.

Clays and glauconitic sands occurring above the debris-flow unit are assigned to the Pliocene. Foraminifers indicate a Tortonian age for the clays below the unconformity, whereas the debris-flow unit contains a Messinian microfossil assemblage (Poag and Low, this volume). Therefore, the observed contact corresponds to 


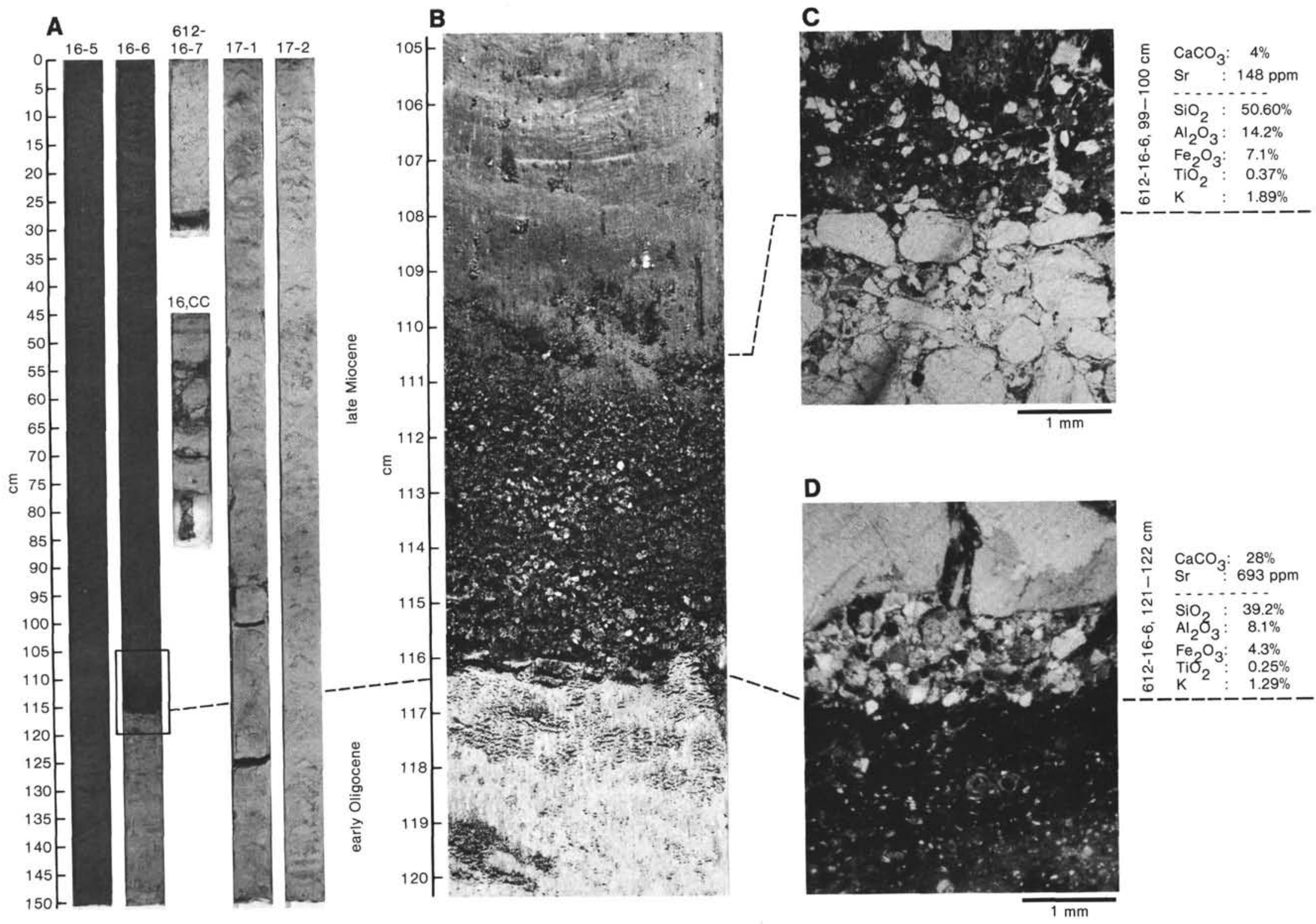

Figure 7. Unconformity between lower Oligocene pelagic chalk and upper Miocene terrigenous sediments at Site 612 . Oligocene lithology is scoured by a 10 -cm-thick layer of coarsegrained glauconitic sand, which underlies the Miocene micaceous clay (A and B, core photos; C and D, microscopic thin sections). Note the increasing terrigenous detrital components above the unconformity. 


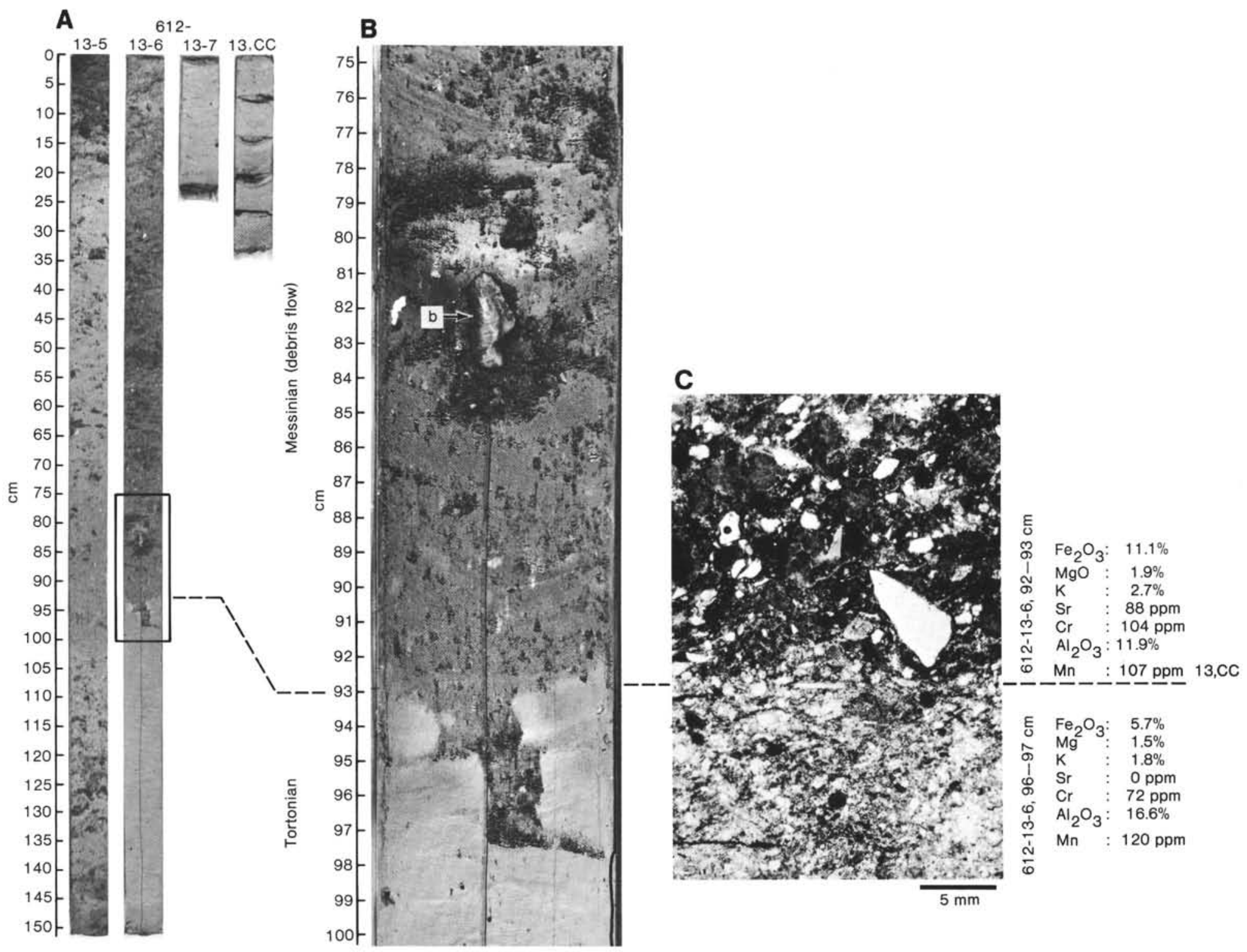

Figure 8. Contact between Tortonian clays and a debris flow unit containing a Messinian microfossil assemblage (Poag and Low, this volume). Note a 3-cm bone fragment (see b in B) and various lithoclasts (C, this section) above the unconformity. The change of geochemical content is related to the presence of glauconite at the base of the debris flow. 
the Tortonian/Messinian contact (or Tortonian/Pliocene, if the debris-flow unit [with its Messinian content] was deposited in the earliest Pliocene).

The Tortonian deposits below the contact (in this section) contain about $25 \%$ coarse silt to fine sand-sized material consisting of angular quartz grains, feldspars, minor glauconite, pyritized microfossils, and terrestrial plant debris in a clay matrix. Similar components occur at the base of the debris flow unit, although the average grain size is larger (range $0.05-1 \mathrm{~mm}$, average $0.3 \mathrm{~mm}$ ): $30 \%$ glauconite, $15-20 \%$ quartz, minor feldspar, mica, and a clay matrix.

The transition between these two facies is abrupt, although thin section may show the contact to be blurred over a few tenths of millimeters, probably a result of the debris flow eroding into the underlying poorly consolidated clay.

The sudden appearance of glauconite above the contact results in a notable increase in $\mathrm{Fe}_{2} \mathrm{O}_{3}, \mathrm{MgO}, \mathrm{K}, \mathrm{Sr}$, and $\mathrm{Cd}$, and a decrease in $\mathrm{Al}_{2} \mathrm{O}_{3}$ and other elements present in clays.

The dynamic conditions of sedimentation are the main features of this unconformity. The presence of a debris flow unit suggests seafloor instability upslope.

\section{Pliocene/Pleistocene Contact (Fig. 9)}

In Sample 612-5-3, $35 \mathrm{~cm}$ the typical Pliocene alternating clay and glauconitic sand becomes (upward) homogeneous gray, bioturbated clay. This lithologic contact corresponds to a biostratigraphic gap; nannofossils in Sample 612-5-3, $45 \mathrm{~cm}$ are assigned to the late Pliocene, whereas those in Sample 612-5-3, $32 \mathrm{~cm}$ are assigned to the late Pleistocene. The lower Pleistocene is absent. As the glauconite is a typical Pliocene feature, we place the unconformity at the top (not the bottom) of the uppermost glauconitic zone (Sample 612-5-3, 35 $\mathrm{cm}$ ) (see Poag and Low, this volume).

Thin sections show that there are three distinct layers:

1. At the base (a), the top of the 4- to 5-cm-thick sequence of glauconite sand, the grain size ranges from 50 to $300 \mu \mathrm{m}$ with an average of $250 \mu \mathrm{m}$. These sands contain $35-40 \%$ glauconite and $30 \%$ quartz, associated with feldspar, green amphibole, tourmalines, pyrite, and mica (especially biotite) in a clay matrix. The glauconite grains are frequently surrounded either by a fibrous ring (perhaps a result of recrystallization or chemical precipitation; see Fig. 9) or by the pyritic clusters (which indicate a reducing environment). In addition, the micas in the matrix are oriented oblique to bedding, possibly a result of turbidity current deposition.

2. At the top (c), the sediment consists of brown clay containing a small amount (3-7\%) quartz, feldspars, and silt-sized mica. There are occasional coarser layers $\left(\mathrm{c}^{\prime}\right.$; $0.5-1.5 \mathrm{~mm}$ thick) with an increased content (10-20\%) of angular, coarse silt-sized quartz and feldspar grains. The stratification is irregular and disturbed (possibly a result of currents or synsedimentary slumps).

3. Between a and c a dark, discontinuous layer (b), about $1 \mathrm{~mm}$ thick, showing thin laminations on a microscopic scale. The dark color is variably disseminated in the sediment or concentrated in well-defined zones. This could be the result of oxides that formed from flu- ids circulating in the sediment and possibly in part related to the presence of organic matter. Lighter layers, rich in quartz, feldspars, and mica (b') are interbedded. A few grains of carbonate were also observed, as well as small feldspars, partially etched and infilled with glauconite.

Significant geochemical changes occur between Samples 612-5-5, 10-14 cm and 612-5-2, 10-14 cm. Increases in $\mathrm{CaCO}_{3}, \mathrm{MgO}, \mathrm{Na}, \mathrm{Sr}$, and $\mathrm{Cu}$ and decreases in $\mathrm{Fe}_{2} \mathrm{O}_{3}, \mathrm{~K}, \mathrm{~V}$, and $\mathrm{Cr}$ are observed (Fig. 9). The sampling interval here is relatively large, but sufficient to demonstrate a coincidence between the geochemical and lithologic variations. In this context, the geochemical data are in agreement with the upper Pleistocene enrichment in calcareous microfauna and clay, and also with the decrease (and even disappearance) of glauconite in the sediment.

Furthermore, an unusual change in the clay fraction is observed: kaolinite and smectite decrease and chlorite and illite increase (J. Thein and Schafer, unpubl. data). This could be the result of active erosion (producing detrital minerals) in place of chemical weathering on the adjacent continental area. This suggests the influence of both climatic change and rapid sea level fall related to the Pleistocene glaciation.

To summarize, the unconformities are characterized by (Figs. 3,4$)$ : (1) changes in the facies and mineralogic composition of the surrounding sediments; (2) association with a biostratigraphic gap; and (3) the presence of an erosional surface.

Based on these criteria, not all the unconformities are of equal importance. Unconformities having minor hiatuses include the Campanian/Maestrichtian contact and the Miocene/Pliocene contact. One of the major presumed significant unconformities, the Cretaceous/Tertiary contact, was not directly observed at Site 612, as a result of poor recovery. The most dramatic unconformity observed at Site 612 is the Paleogene/Neogene contact, which separates pelagic from terrigenous deposits and is associated with a $25-\mathrm{m} . y$. biostratigraphic gap. However, this erosion is restricted to a few local channels (Poag and Mountain, this volume). These partial results, based only on Hole 612 , must be compared to data of other sites and to a regional seismic grid to reveal their relative regional importance (see Poag and Mountain, this volume, for such comparisons).

\section{SITE 612 UNCONFORMITIES AND THE EVOLUTION OF THE ATLANTIC MARGIN}

The purpose of this section is to outline possible origins for the erosional surfaces and accompanying biostratigraphic gaps and lithologic changes associated with the unconformities of Site 612 and the surrounding New Jersey margin. Data relative to similar unconformities described from other passive margins reveal two important factors as possible erosive agents: bottom currents and fluctuations in relative sea level.

In the depositional model of Vail et al. (1977), unconformities and condensed sections on the continental margin and in deep basins are considered to be the result of sea level fluctuations. During high stands of sea level, terrigenous sediments are often trapped on the conti- 


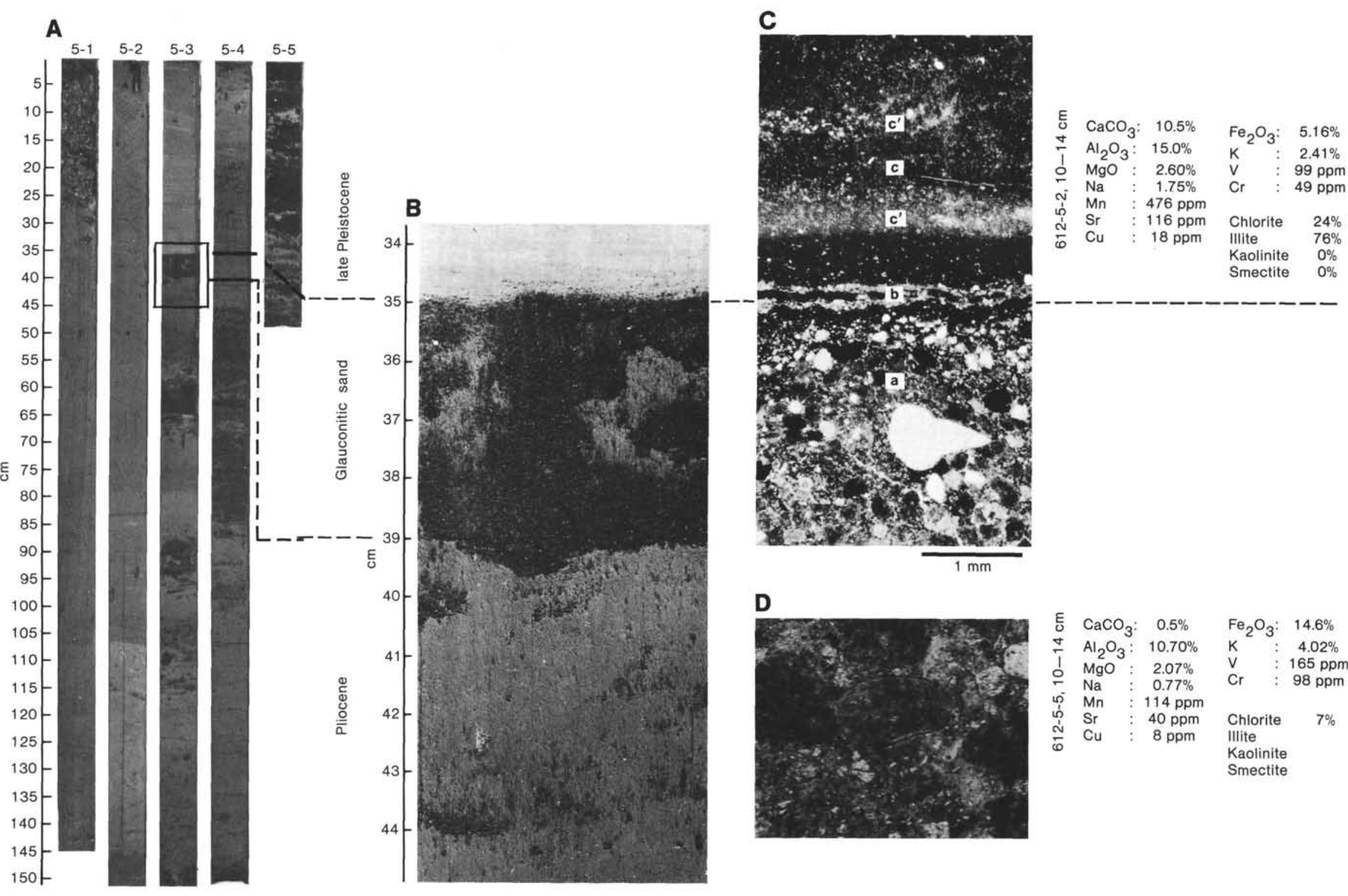

Figure 9. Contact between the Pliocene alternating clay and glauconite sand and the upper Pleistocene homogeneous clay at Site 612; a, b, c, (C): various lithologies present at the top of the glauconitic sand and the base of the Pleistocene clay (description in text); D, detail of glauconite grain surrounded by a fibrous rim. Note an upward-increasing chlorite and illite content related to active erosion of the adjacent continental area. 
nental shelf, while during low stands the continental shelf may be exposed to erosion. In the latter case, terrigenous material may be transported down submarine canyons or distributed in other ways down the continental slope, leading to construction of deep-sea fans or other displaced deposits on the continental rise. Exceptions to this model may exist: some stratigraphic gaps observed on the continental rise coincide with a decrease in relative sea level rather than an increase (the Oligocene gap on the Goban Spur margin, for example). This anomaly in the model may be explained by other processes, such as bottom currents.

Bottom current influences were detailed by Heezen and Hollister (1964). As they are involved in submarine erosion, they are important factors in considering the evolution of the slope and rise deposits.

Relative sea-level fluctuations and bottom current activity depend on subsidence and tectonism of the margin, global sea-level changes (eustatism), climatic aspects (primarily glaciation), and kinematic evolution. Their relative importance through time is considered below in relation to the history of the Atlantic margin.

\section{Atlantic Margin Evolution since the Late Cretaceous}

A geodynamic reconstitution of the Atlantic Ocean at $76 \mathrm{Ma}$ (early Campanian: Anomaly 33; Olivet et al., 1980-1984; Sclater and Tapscott, 1980) shows that the central area had already acquired modern topographic features, whereas northern and southern regions of the Atlantic were undergoing great changes. At this time, relative sea level fluctuations on the New Jersey margin were probably controlled by the subsidence rate of the margin and eustatic sea level changes.

Based on models by Watts and Thorne (1984), the subsidence of the margin would have increased the effect of sea level rise up to the Late Cretaceous; toward the end of the Cretaceous, subsidence and eustatic sea level fall had the same rate (stationary relative sea level); during the Paleocene and Oligocene, subsidence was so slow as to have the effect of increasing the effect of sealevel fall; during the Eocene and Miocene, subsidence was faster than sea-level decrease and thus slowed the effects of global rising sea level. Similar relative sea-level fluctuations are qualitatively represented on the Vail and Hardenbol (1979) curve based on coastal onlap (Fig. 10).

Another important factor is glaciation. Some authors (Davies et al., 1975) believe that the Antarctic polar ice caps existed as long ago as the Eocene. Miller and Fairbanks (1983) have provided benthic foraminiferal oxygen isotope evidence for three glacial episodes dated 36-35 Ma (early Oligocene), 31-28 Ma (early Oligocene/ late Oligocene boundary), and 25-24 Ma (late Oligocene). Another glacial phase occurred in the middle Miocene, according to Savin et al. (1975), which coincided with expansion of the Antarctic ice cap. Finally, Arctic glaciation began in the late Pliocene. These events caused: rapid sea-level falls (glacioeustatic), pronounced lithologic changes (especially in the composition of terrigenous material), and changes in bottom water sources (and thereby bottom currents).
The location and velocity of bottom currents depend also on oceanic circulation. Published kinematic data (Olivet et al., 1980-1984; Sclater and Tapscott, 1980) show that connections between the New Jersey margin and potential sources of cool Arctic water (Greenland-Norwegian Sea) and Antarctic sources (Weddell Sea) were established by stages. The main ones are the opening of the Labrador Sea (76 Ma, Campanian) and of the Reykjanes and Arctic basins (Norwegian Sea, $53 \mathrm{Ma}$, early Miocene); this was followed by the subsidence of the Rio Grande and Walvis ridges (36 Ma, late Eocene to early Oligocene) and the Iceland-Faeroe Ridge. It appears that these events may have influenced bottom water circulation.

\section{Interpretation of Unconformities at Site $\mathbf{6 1 2}$}

We have used three types of data to interpret the unconformity record at Site 612: (1) the bathymetric, kinematic, and climatic framework and its evolution since the Late Cretaceous; (2) the comparative sedimentological analysis of unconformities at sites along the New Jersey Transect (Fig. 10); and (3) their spatial distribution along a cross section of the continental slope (Fig. 2a, after Poag, 1985b), completed by the results of integration of borehole data with seismic reflection profiles (Poag and Mountain, this volume).

The seismic profiles show that the 25-m.y. gap at Site 612 between the Paleogene and Neogene is because of a small buried channel, which is filled by Tortonian, Messinian, and Pliocene strata (Poag and Low, this volume; Poag and Mountain, this volume). On the New Jersey slope, other channels truncate the Oligocene, early Miocene, and middle Miocene strata (Lines 69, 89, 105, etc.; Poag and Mountain, this volume). Truncations and erosion of these channels took place near the SerravallianTortonian transition (Poag and Mountain, this volume). This erosive event coincides with a relative sea-level fall (approximately $10 \mathrm{Ma}$; see Vail and Hardenbol curve in Figure 10), and a glacial period (maximum development of the Antarctic ice cap; Savin et al., 1975).

Because a 25-m.y. gap separates the Paleogene and older hemipelagic deposits from the overlying Neogene terrigenous deposits at Site 612, this facies change is not assigned to a precise period, but it is reasonable to assume a contemporaneous age for this shift over the entire New Jersey margin. Figure 10 shows that at Site 612, chalk occurs up to Zone P18 (early Oligocene, approximately $35 \mathrm{Ma}$ ), whereas the oldest terrigenous sediments (sands and clays) of the New Jersey Transect are part of Zone P21 (upper Oligocene, approximately $30 \mathrm{Ma}$ ) in the COST B-2 and B-3 wells. Therefore, the geological event responsible for the change in sedimentary regime is intra-Oligocene. Miller et al. (1985) have observed that on the lower part of the continental slope, offlap and canyon cutting can be correlated with rapid glacio-eustatic sea-level falls assigned to the early and middle Oligocene.

Therefore, between the lower Oligocene and upper Miocene (Tortonian), at least two unconformities are present in the New Jersey area: (1) channeling, erosional sur- 

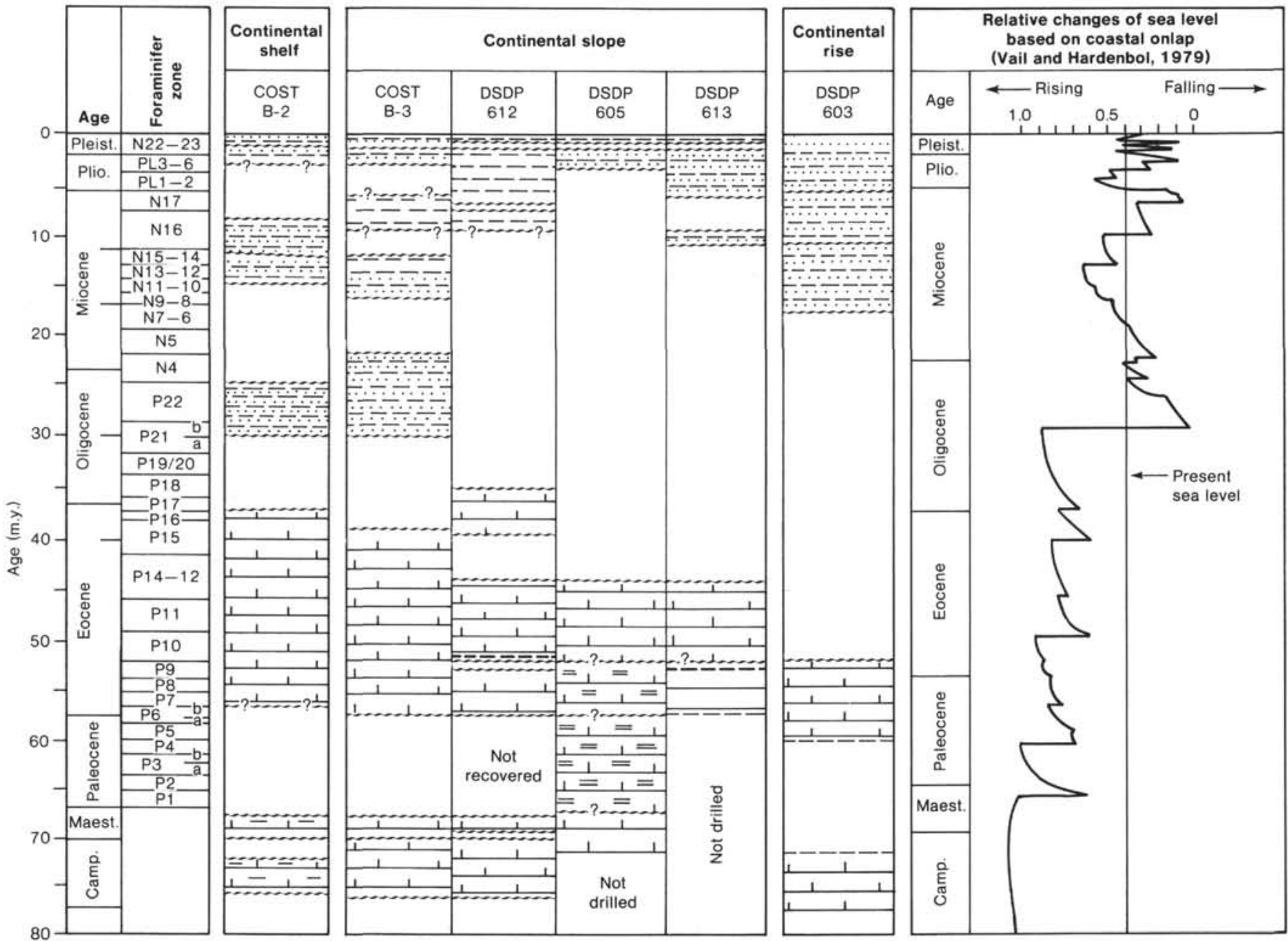

Figure 10. Unconformities along the New Jersey Transect (modified from Poag, 1985b), correlated with the relative changes of sea level based on coastal onlap (from Vail and Hardenbol, 1979). Blanks in the geologic columns represent missing sections. Some of the stratigraphic boundaries differ slightly from those utilized by Poag (1985b) and Vail and Hardenbol (1979).

faces, local gaps, and accompanying important changes of facies characterize the mid-Oligocene; (2) a truncating and channeling event occurred at the Messinian-Tortonian transition. Both can be related to sea-level falls and glacio-eustatic events. At Site 612, both these unconformities have coalesced as a single erosional surface.

The Pliocene/late Pleistocene unconformity (No. 7) reveals two influences of glaciation: (1) a relative sealevel fall led to erosion on the upper part of the margin (early Pleistocene gap); (2) on the continent, a cooler climate largely stopped chemical weathering (decrease in smectite influx) and activated the input of purely detrital clay minerals (illite and chlorite).

Pre-Oligocene unconformities cannot be explained by glacio-eustatism; the changes in relative sea level may be related to changes in mid-ocean ridge volume (Pitman, 1978) and relative rates of margin subsidence (Watts and Steckler, 1979; Watts and Thorne, 1984). A qualitative representation of sea-level changes is given by Vail and Hardenbol (1979; see also Fig. 10). Moreover, the deep ocean basins have become progressively more open to bottom water circulation since the Late Cretaceous. As already noted, the Campanian/Maestrichtian contact
(No. 1) coincides with upward-decreasing clay content and may be related to a sea level still stand. It is a widespread regional unconformity on the North American Atlantic margin, but is associated at Site 612 with only a small stratigraphic gap.

Unconformity No. 2 (Cretaceous/Tertiary contact) is difficult to interpret because of the lack of samples at the level of the contact. The hemipelagic unit (Cretaceous: more or less siliceous clayey chalk), and the pelagic unit (Eocene: biosiliceous chalk) are separated by a 9-m-long unrecovered interval. On the continental shelf (COST B-2 well) and on the upper slope (COST B-3 well), a 10-m.y. biostratigraphic gap occurs between the Cretaceous and Tertiary (Poag, 1985b). On the contrary, downslope (Site 605) the gap is quite small (van Hinte, Wise, et al., in press); the Paleocene is thick at Site 605 and shows an increase in clay content. Both erosion of the upper margin and increase in clay content are probably the result of sea-level fall.

The siliceous diagenetic "front" observed at Sites 612, 613, and 605 (see interpretation in Thein and von Rad, this volume) occurs $8 \mathrm{~m}$ above the unconformable lower/ middle Eocene contact at Site 612, but no biostratigraphic 
gap has been recognized associated directly with the "front." A well-defined unconformity also occurs between the middle and upper Eocene. In both cases (lower/middle Eocene and middle/upper Eocene unconformities), an erosional surface may be associated with a relative lowering of sea level (Fig. 10; Vail and Hardenbol, 1979).

\section{CONCLUSIONS}

Before the Oligocene, the main factor causing unconformities at Site 612 (relative sea-level changes) apparently depended on the interaction between changes in mid-ocean ridge spreading rate and subsidence rates on the margin. Therefore the Campanian/Maestrichtian contact, associated with decreasing clay, may be related to a relative sea-level still stand; the other unconformities (Cretaceous/Tertiary contact, early/middle Eocene, middle/ late Eocene) are presumably associated with a relative sea-level fall.

Since the Oligocene, glacial events have played an important role in causing erosion. Global sea-level changes caused by glacio-eustatism were relatively rapid, causing erosional surfaces, channeling and truncation, debris flows and slumps. Poag and Mountain (this volume) infer that downslope displacement of sediments formed all the unconformities at Sites 612, 613, 604, and 605 .

Important changes in the facies and mineralogic composition of the sediments also resulted from climatic shifts associated with glaciation. A rejuvenation of the topography of the adjacent continental areas, caused by relative sea-level fall, provided increased volumes of terrigenous material to the offshore region. The change in climatic conditions is also seen in the composition of the terrigenous sediment; the abundance of primary detrital minerals (chlorite, illite) increases, and smectites decrease. This phenomenon has been characteristic of the central Atlantic since the Oligocene, and continue up to the present (Chamley, 1979). Changes observed on the New Jersey margin are in agreement with this widespread Atlantic record.

Glaciations, associated with kinematic adjustments, theoretically may accelerate bottom water circulation, which mainly influences the lower part of the margin and the deep basin by erosion and nondeposition. However, it is difficult to sort out these influences on the observed unconformities. Nevertheless, some features, such as possible hardgrounds and the broad Eocene outcrop (between Sites 612 and 605) suggest that bottom water circulation was, at times, a significant factor in the development of the New Jersey margin.

\section{ACKNOWLEDGMENTS}

We thank A. Allain for making the thin sections; J. Hernandez and $\mathrm{E}$. Nicot for the observations on the microfacies; G. Boillot, H. Chamley, L. Droz, Y. Lancelot, and D. Mougenot for discussions and comments on the manuscript; C. W. Poag for critically reviewing the manuscript; Y. Descatoire for drawing the figures; V. Leclerc for translating the French version; and A. Palmer for the rewritten version of our manuscript.

\section{REFERENCES}

Chamley, H., 1979. North Atlantic clay sedimentation and paleoenvironment since the Late Jurassic. In Talwani, M., Hay, W. W., and Ryan, W. B. F. (Eds.), Deep Drilling Results in the Atlantic Ocean: Continental Margins and Paleoenvironment: Washington (Am. Geophys. Union), Maurice Ewing Series, 3:342-360.

Davies, T. A., et al., 1975. Unconformities in the sediments of the Indian Ocean. Nature, 253:15-19.

Grow, J. A., 1980. Deep structure and evolution of the Baltimore Canyon Trough in the vicinity of the COST No. B-3 well. U.S. Geol. Surv. Circ., 833:117-132.

Heezen, B. C., and Hollister, C. D., 1964. Deep-sea current evidence from abyssal sediments. Mar. Geol., 1:141-174.

Hinte, J. E. van, Wise, S. W., Jr., et al., in press. Init. Repts. DSDP, 93: Washington (U.S. Govt. Printing Office).

Miller, K. G., and Fairbanks, R. G., 1983. Evidence for Oligocenemiddle Miocene abyssal circulation changes in the western North Atlantic. Nature, 306:250-252.

Miller, K. G., Mountain, G. S., and Tucholke, B. E., 1985. Oligocene glacio-eustacy and erosion on the margins of the North Atlantic. Geology, 13:10-13.

Olivet, J. L., Bonnin, J., Beuzart, P., and Auzende, J. M., 1980-1984. Cinématique de l'Atlantique Nord et Central. Planches I-IV, 1980; Rapport Scientifique et Technique No. 54, C.N.E.X.O., 1984.

Pitman, W. C., III, 1978. Relationship between eustacy and stratigraphic sequences of passive margins. Geol. Soc. Am. Bull., 89: 1389-1403.

Poag, C. W., 1980. Foraminiferal stratigraphy, paleoenvironments, and depositional cycles in the outer Baltimore Canyon Trough. U.S. Geol. Surv. Circ., 833:44-65.

1985a. Depositional history and stratigraphic reference section for central Baltimore Canyon Trough. In Poag, C. W. (Ed.), Geologic Evolution of the United States Atlantic Margin: New York (Van Nostrand Reinhold), pp. 217-264.

, 1985b. Cenozoic and Upper Cretaceous sedimentary facies and depositional systems of the New Jersey slope and rise. In Poag, C. W. (Ed.), Geologic Evolution of the United States Atlantic Margin: New York (Van Nostrand Reinhold), pp. 343-365.

Robb, J. M., Kampson, J. C., Kirby, J. R., and Twickell, D. C., 1981. Geology and potential hazards of the continental slope between Lindenkohl and south Tom's Canyons, offshore mid-Atlantic United States. U.S. Geol. Surv., Open File Rept., 81.600:1-38.

Savin, S. M., Douglas, R. G., and Stehli, F. G., 1975. Tertiary marine paleotemperatures. Geol. Soc. Am. Bull., 86:1499-1510.

Schlee, J. S., and Grow, J. A., 1980. Seismic stratigraphy in the vicinity of the COST No. B-3 well. U.S. Geol. Surv. Circ., 833:111-116.

Sclater, J. G., and Tapscott, C., 1980. L'histoire de l'Atlantique. La Dérive des Continents: New York (Scientific American), pp. 106119.

Vail, P. R., and Hardenbol, J., 1979. Sea level changes during the Tertiary. Oceanus, 22:71-79.

Vail, P. R., Mitchum, R. M., Todd, R. G., et al., 1977. Seismic stratigraphy and global changes in sea-level. In Payton, C. E. (Ed.), Seismic Stratigraphy-Applications to Hydrocarbon Exploration. Am. Assoc. Pet. Geol. Mem., 26:49-212.

Watts, A. B., and Steckler, M. S., 1979. Subsidence and eustacy at the continental margin of eastern North America. In Talwani, M., W. W., and Ryan, W. B. F., (Eds.), Deep Drilling Results in the Atlantic Ocean: Continental Margins and Paleoenvironment: Washington (Am. Geophys. Union), Maurice Ewing Series, 3:218-234.

Watts, A. B., and Thorne, J., 1984. Tectonics, global changes in sea level, and their relationship to stratigraphical sequences at the U.S. Atlantic continental margin, Mar. Petrol. Geol., 1:319-339.

Date of Original Receipt: 8 January 1986 Date of Acceptance: 3 July 1986 